Research Article

\title{
Determination of the Influence of Fuel Switching Regulation on the Sulfur Dioxide Content of Air in a Port Area Using DID Model
}

\author{
Fan Zhou $\mathbb{D}^{1,2}$ and Yunli Fan $\mathbb{D}^{1,2}$ \\ ${ }^{1}$ College of Information Engineering, Shanghai Maritime University, Shanghai, China \\ ${ }^{2}$ Shanghai Engineering Research Center of Ship Exhaust Intelligent Monitoring, Shanghai, China \\ Correspondence should be addressed to Fan Zhou; fanzhou_cv@163.com
}

Received 13 November 2020; Revised 9 January 2021; Accepted 28 January 2021; Published 9 February 2021

Academic Editor: Antonio Donateo

Copyright (c) 2021 Fan Zhou and Yunli Fan. This is an open access article distributed under the Creative Commons Attribution License, which permits unrestricted use, distribution, and reproduction in any medium, provided the original work is properly cited.

\begin{abstract}
Since January 1, 2018, ships berthed at all ports of the three designated emission control areas (ECAs) in China are required to use fuel with sulfur content not exceeding $0.5 \%(\mathrm{~m} / \mathrm{m})$, excluding one hour postarrival and one hour predeparture. To understand changes in $\mathrm{SO}_{2}$ due to this policy, two observation stations were established on Waigaoqiao Dock in the Yangtze River estuary. Three data types were collected from March 2018 to May 2018, namely, wind speed and direction, $\mathrm{SO}_{2}$ concentration, and ships' arrival and departure times. The statistics indicate that the wind direction changed little during the observation period and $\mathrm{SO}_{2}$ concentration was below $5 \mu \mathrm{g} / \mathrm{m}^{3} 77.47 \%$ of the time. Meanwhile, ships' arrival and departure at the dock had a distinct influence on overall $\mathrm{SO}_{2}$ distribution, including occurrence of concentrations $\geq 5 \mu \mathrm{g} / \mathrm{m}^{3}$. The three types of data were divided into six groups and a difference-in-difference model was used for analysis. The result shows that $\mathrm{SO}_{2}$ concentration increases due to the use of high-sulfur fuel and is especially significant when the wind is southwesterly. Furthermore, there was a positive correlation between increases in $\mathrm{SO}_{2}$ concentrations over $5 \mu \mathrm{g} / \mathrm{m}^{3}$ and the number of ships arriving or departing from the port. This study reports the positive impact of fuel switching on air quality and can be used to evaluate adherence to the ECA policy.
\end{abstract}

\section{Introduction}

With the rapid development of the shipping industry [1], air pollution caused by ship emissions has gained increasing attention in recent years [2-4] as it is a major contributor to both local and global air pollution [5, 6]. To limit ship emissions to the environment and to reduce the risks to human health, the International Maritime Organization (IMO) adopted MARPOL Annex VI in 1997 to prevent air pollution caused by shipping emissions. The main pollutants in ship exhaust are sulfur dioxide, nitrogen oxide, and particulate matter, with $\mathrm{SO}_{2}$ being one of the most prominent pollutants. $\mathrm{SO}_{2}$ comes from the oxidation of sulfur in fuel oil during combustion. Hence, high average sulfur in fuel oil leads to high $\mathrm{SO}_{2}$ emissions [7]. The regulation of IMO included a global cap of fuel sulfur content (FSC) such that it should not exceed $3.5 \%(\mathrm{~m} / \mathrm{m})$ (as of 2012) and should be reduced to $0.5 \%(\mathrm{~m} / \mathrm{m})$ by 2020 [8]. The IMO regulation also included the establishment of emission control areas (ECAs), where the FSC should not exceed $0.1 \%(\mathrm{~m} / \mathrm{m})$ as of 2015 [9]. In addition, some countries and regions have set their own ECAs. For instance, the Atmospheric Pollution Prevention and Control Law of the People's Republic of China was promulgated in 2015 [10]. In the subsequent implementation plan, three domestic ECAs were set up by the Chinese government, namely, the Yangtze River Delta, the Pearl River Delta, and Bohai Rim (also referred to as the Beijing-Tianjin-Hebei Region) [11]. Under these regulations, FSC cannot exceed $0.5 \%(\mathrm{~m} / \mathrm{m})$ during berthing within ECAs, excluding one hour following the ships' arrival at the dock and one hour before its departure, January 1 , 2018, onwards.

Yangtze River is the world's third-largest river and China's most important inland waterway. Yangtze River Delta is within the ECAs. Located at the mouth of the Yangtze River, Shanghai is one of the most prosperous cities 
worldwide. At the end of 2017, Shanghai had a permanent resident population of approximately 24 million people [12]. Container traffic through Shanghai increased each year from 2010 to 2018 to become the busiest port in the world. As such, it is important to understand the impact ship pollution has on air quality in this area [13-15]. There are currently two major ports in Shanghai: Yangshan and Waigaoqiao. The Waigaoqiao Port is only $20 \mathrm{~km}$ from the city center, and air pollution caused by ship emissions in this area directly affects the urban air environment and the health of Shanghai's residents. A previous study indicated that $70 \%$ of the global emissions from ships are produced within $400 \mathrm{~km}$ of coastlines and that these emissions can cause severe environmental and health problems within these regions $[16,17]$. Filonchyk and Peterson (2020) evaluated air quality during the COVID-19 lockdown of Shanghai and found that daily concentrations of PM2.5, PM10, $\mathrm{SO}_{2}, \mathrm{NO}_{2}$, and $\mathrm{CO}$ during the lockdown period were reduced by $9 \%, 77 \%$, $31.3 \%, 60.4 \%$, and $3 \%$, respectively, compared to the same period in 2019 [18]. Therefore, the mitigation of ship exhaust emissions and the establishment of sustainable port ecosystems have become urgent tasks that require complex and comprehensive systematic approaches [19]. Thus, as one of the busiest ports worldwide, it is important to understand and control the pollution from ships in Waigaoqiao Port.

Previous studies have indicated that ship emissions observed at the monitoring stations in ECAs have decreased significantly since the aforementioned restrictions were implemented [20-24]. Accordingly, this study monitored the $\mathrm{SO}_{2}$ concentrations at the dock within the China's ECAs from March 2018 to May 2018. Ship owners are likely to use cheaper heavy fuel during arrival or departure at the dock to reduce fuel costs while staying within the bounds of the policy. When a ship is berthed, light fuel is likely used instead. Therefore, in this study, changes in $\mathrm{SO}_{2}$ concentrations were used to understand the impact of the Atmospheric Pollution Prevention and Control Law on air quality.

Regarding methods for monitoring ship emissions, landbased measurements provide continuous observations and have been widely used. Kattner et al. [21] reported large reductions of $\mathrm{SO}_{2}$ in ship plumes from September 2014 to January 2015 near the mouth of Hamburg Harbor on the River Elbe. Their results show that the vast majority (95.4\%) of all the ships complied with the regulation of $0.1 \%$ FSC. Yang et al. [22] measured $\mathrm{SO}_{2}$ continuously from the Penlee Point Atmospheric Observatory near Plymouth, United Kingdom, between May 2014 and November 2015; this coastal site is exposed to marine air across a wide wind sector. Their observations suggest a 3-fold reduction in ship emitted $\mathrm{SO}_{2}$ from 2014 to 2015. Alfoldy et al. [24] measured the chemical composition of the plumes of seagoing ships during a two-week-long measurement campaign in the port of Rotterdam, Hoek van Holland, Netherlands, in September 2009. The average $\mathrm{SO}_{2}$ emission factor was found to be approximately half of what is allowed in ECAs, and exceedances of this limit were rarely registered. Beecken et al. [25] carried out measurements from coastal sites near the island of Kronstadt and along the Neva River in the urban area of Saint Petersburg. The emission factors show compliance with the 1\% FSC ECAs limit for $90 \%$ of the ships in 2011 and 97\% in 2012. Murena et al. [26] assessed the impact of cruise ship emissions in the port of Naples on air quality using a bottom-up procedure. They concluded that cruise ships' contribution seems limited but nonnegligible. These studies show that land-based monitoring can monitor ship emissions accurately. Meanwhile, various studies have been conducted to clarify the environmental impact of China's ECAs policy. The research of Zhang et al. [27] indicated that the $\mathrm{SO}_{2}$ concentration in Shanghai decreased by at least $0.229 \mu \mathrm{g} / \mathrm{m}^{3}$ daily on average due to the implementation of the ECA policy. Wan et al. [28] compared and analyzed the changes of air quality in port cities within and outside the ECAs during the implementation of the policy. The results showed that the ECA policy has some time lag, possibly because enforcement has gradually become more stringent. Zhang et al. [29] conducted a measurement campaign (SEISO-Bohai) from December 28, 2016, to January 15, 2017, at Jingtang Harbor, an area within China's ECAs. The results from this study indicated a positive impact from fuel switching on the air quality in the study region. From these studies, it can be seen that the monitoring of ship emissions in ECAs can help evaluate the implementation effect of the policy.

At present, the requirement of China's ECAs is mainly aimed at the limitation of sulfur content in ship fuel. Ship emissions of sulfur oxides (mainly $\mathrm{SO}_{2}$ ) come from the sulfur content of fuel. Therefore, by detecting the change of $\mathrm{SO}_{2}$ content in the dock in combination with the berthing information of the ship, the influence of the restriction policy on the air quality in the port area can be judged. As an alternative to the observation position of the above research, the dock area is not only the heaviest traffic area but also the main area from which the maritime department supervises and enforces laws. An understanding of ship emissions and atmospheric processing in dock areas is required in order to develop effective regulations to better manage the environmental impacts of shipping. Therefore, $\mathrm{SO}_{2}$ monitoring equipment was installed on the bridge cranes of Waigaoqiao Dock. We were allowed to observe the changes in sulfur dioxide in the intensive shipping area from March 2018 to May 2018. Ships' arrival and departure times from the port and the wind speed and direction were also collected for comparative analysis. The main purpose of this research was to clarify the impact of ECA policy on air quality in port areas. However, as the port area is a relatively complex environment, it is difficult to accurately assess the impact of the policy based on existing observational data. In policy evaluation research, the difference-in-difference model (DID) is an effective tool to extrapolate the causal effects of policy $[27,28]$. The primary application of the DID model is to estimate the difference in the mean outcomes of the treated and control units posttreatment and to isolate the outcome difference that existed before the treatment [30]. Meanwhile, ships' arrival and departure times and wind speed and direction are the two main factors affecting $\mathrm{SO}_{2}$ concentration which were also monitored. The monitoring dataset is suitable for the comparison experiment using the 
DID model. Therefore, we used the DID model to analyze the collected data. This can be employed to identify the impact of reducing $\mathrm{SO}_{2}$ emissions in policy-affected regions.

\section{Methods}

2.1. Measurement Site. As shown in Figures 1(a) and 1(b), the measurement station is located on the south bank of the Yangtze River estuary in the Waigaoqiao Port area, north of Shanghai. In December 2018, the Waigaoqiao Port handled 1,747,000 teU, 14.987,000 tons of cargo, and 3,553 berthing vessels. In previous studies [21, 25, 29], the monitoring station has been located on the shore of the channel. Under an appropriate wind speed and direction, the monitoring stations used in previous studies can measure the emissions of a single ship that sails through the port. However, in this study, the monitoring equipment was located on the suspension bridge on the dock, as shown in Figure 1(c). We deployed two sets of equipment on two different working bridge cranes approximately $1 \mathrm{~km}$ apart. During the task of loading/unloading containers, the bridge crane moved three dimensionally within a small area, thus the position of the monitoring equipment varied (30-40 $\mathrm{m}$ in height) though this did not affect the outcome. The bridge crane is mostly surrounded by container ships berthing. The research of Chen et al. [31] indicated that the main contributors to ship emissions are containers, followed by fishing ships, oil tankers, and bulk carriers. Therefore, the equipment on the bridge crane can clearly detect changes in $\mathrm{SO}_{2}$ from its location. The complexity of the monitoring points within the surrounding environment is shown in Figures 1(a) and 1(b). Sources of airborne $\mathrm{SO}_{2}$ are the ships that are in berth as well as ships that are sailing far from the dock; at the same time, container trucks on the docks are also a source of $\mathrm{SO}_{2}$. In addition, it can be seen from Figure 1(b) that the surroundings of monitoring points 1 and 2 differ, and there are more ship berths to the west of monitoring point 2. Higher concentrations of $\mathrm{SO}_{2}$ may be detected when there are westerly winds. Therefore, in this study, we analyzed the correlation between the factors (wind speed and direction and ships' arrival and departure at the dock) and the observed results $\left(\mathrm{SO}_{2}\right.$ concentration) rather than the emissions from individual ships.

2.2. Instrumentation. In this research, $\mathrm{SO}_{2}$ was measured with instruments from the ETL3000 series, the sensors (Unitec SENS-IT) of which meet the European Standard 2008/50/EC. As shown in Figure 1(c), the monitoring equipment employed in this study had a measured weight of $12 \mathrm{~kg}$, a solar power supply system, and the data communication mode was $4 \mathrm{G}$ cellular broadband. It included a data acquisition and processing unit, modular gas sensor, solar power supply system, and wireless data transmission module and a software system that was directly installed outdoors without any cooling device or air-processing device. The $\mathrm{SO}_{2}$ sensor used the electrochemical method, where the electrochemical sensor determined the concentration of the gas through a redox reaction and produced an electrical signal proportional to the concentration of the gas. The $\mathrm{SO}_{2}$ electrochemical sensor was efficient in terms of its low power consumption, small size, and lightweight and being extremely precise. Additionally, these sensors were capable of measuring $\mathrm{SO}_{2}$ concentrations at a low ppb range [32], with a resolution level of $1 \mathrm{ppb}$, an accuracy of $20 \mathrm{ppb}$, and a measuring range of 5 to $10,000 \mathrm{ppb}$. Overall, this kind instrumentation is convenient and lightweight, which is appropriate for installation on a bridge crane.

2.3. Data Treatment. Three types of data at the monitoring dock were collected from March 2018 to May 2018: wind speed and direction, the concentration of $\mathrm{SO}_{2}$, and ships' arrival at and departure from the dock. $\mathrm{SO}_{2}$ concentration was measured once per minute from the two monitoring points. The data from March and April are continuous data, with observation times of 743 hours and 720 hours, respectively. Due to the receiver server failure, there is a certain degree of missing data in May. Data were gathered from 14 : 00 on May 1 to $14: 00$ on May 4 and from $0: 00$ on May 10 to 24:00 on May 21. The total observation time for May was 354 hours.

The three sets of data were normalized using each hour's data in order to facilitate a comprehensive analysis. Using this methodology, the 2 minutes of average wind speed and direction data that were collected and the mean values of $\mathrm{SO}_{2}$ concentrations observed at the two monitoring stations were each considered as one-hour observations. The ships' arrival and departure times at the dock were recorded within each hour as one-hour observations. Then, $\mathrm{SO}_{2}$ concentration data were organized into six groups based on the month and the monitoring points, as follows: Monitor-1 in March, Monitor-2 in March, Monitor-1 in April, Monitor-2 in April, Monitor-1 in May, and Monitor-2 in May. These data were then analyzed to identify the $\mathrm{SO}_{2}$ emission characteristics and their relationship with wind speed, wind direction, and ships' arrival and departure.

Several aspects influenced the results of the analysis. As can be seen from Figure 1, in addition to nearby berthing ships, the monitoring point also was able to collect data for ships sailing in the distance and container trucks passing under the bridge crane. There are also many chemical plants within $10 \mathrm{~km}$ of the dock; the $\mathrm{SO}_{2}$ emitted from these sources will have impacted the measurements, which can increase uncertainty. Preliminary studies showed that $1-19 \%$ of the sulfur in the fuel is emitted in other forms, possibly $\mathrm{SO}_{3}$ or $\mathrm{SO}_{4}$ [33-36]. Hence, the assumption that all sulfur is emitted as $\mathrm{SO}_{2}$ yields an underestimation of the true sulfur content in the fuel. In addition, the research of Yang et al. [22] shows that the residence time of $\mathrm{SO}_{2}$ in the marine atmosphere is approximately $0.5 \mathrm{~d}$, with dry deposition explaining about a quarter of the total $\mathrm{SO}_{2}$ sink. Therefore, the $\mathrm{SO}_{2}$ measured by the sensor may be either from the ship that is emitting it or from ship emissions within half a day. Unfortunately, there are no quantitative data for the abovementioned uncertainty. Although the background value can approximate from the observed value when there is no ship, the endogenous problems arise when reverse 


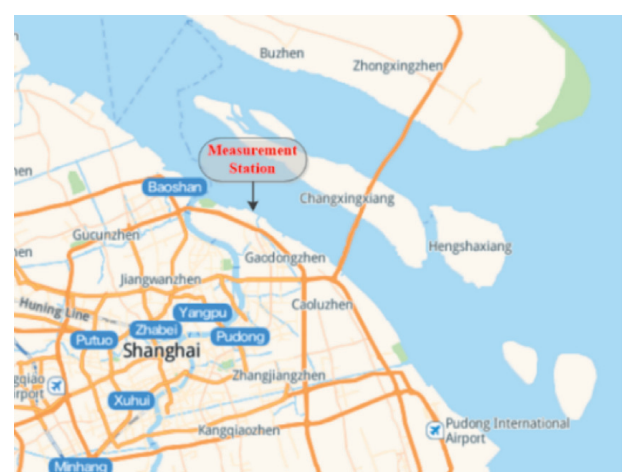

(a)

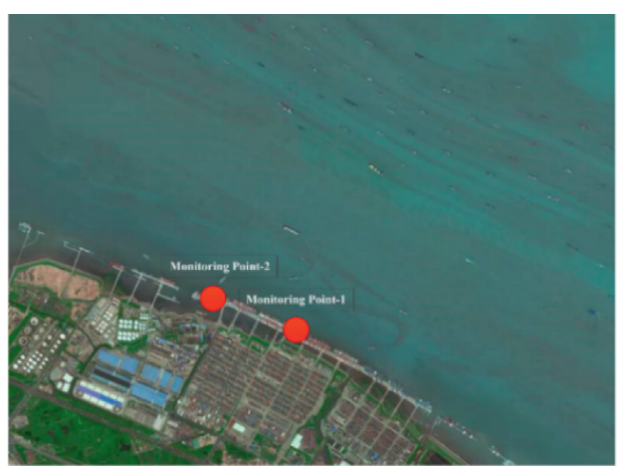

(b)

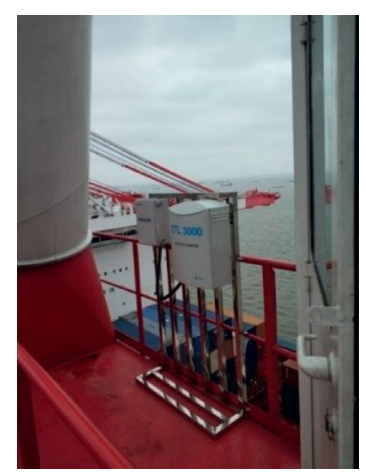

(c)

FIgURE 1: (a) Location of the measurement station. (b) Satellite view of the monitoring environment, with the location of the two survey stations shown in red (map source: lbs.amap.com). (c) Equipment installed at a suspension bridge on the dock.

causality occurs between the variables or some variables are missing. However, by using the DID model, the observation data are robust enough that they can provide useful inferences. It can be defined as follows:

$$
Y_{i t}^{1,2}=\alpha_{0}+\alpha_{1} d u+a_{2} d t+a_{3} d u * d t+a_{4} Z_{i t}+\varepsilon_{i t},
$$

where subscripts $i$ and $t$ represent the $i$-th monitoring point and $t$-th month, respectively, and superscripts 1 and 2 represent monitoring points 1 and 2 , respectively. $Z$ represents a series of control variables, $\varepsilon$ is a random term (or disturbance), and the interpreted variable is the monitored $\mathrm{SO}_{2}$ value.

According to the ECA policy, ships are allowed to use high-sulfur fuel within one hour of their arrival or departure. To analyze the influence of this factor on air quality, we used $d t$ as the control parameter. $d t=1$ means that a ship arrived or departed the dock during this hour; otherwise, $d t=0$. Wind direction is also a major influencing factor. $d u$ was used as the control parameter to classify the monitoring data of downwind (wind direction: 180-270 degrees) as the treatment group and the nondownwind data as the control group. Because the treatment group and the control group are measured by the same equipment at the same location, they meet the parallel trend required by the DID model. When $d u=1$, the monitoring equipment is leeward of the berthing ships; that is, the discharge of the berthing ships is mainly measured by the monitoring equipment. Otherwise, $d u=0$. The DID model parameters are explained according to the above definition as listed in Table 1.

\section{Results and Discussion}

The overall distribution of the average $\mathrm{SO}_{2}$ concentrations per hour observed at the two monitoring points is shown in Figure 2. It can be seen that the concentration of $\mathrm{SO}_{2}$ is mainly distributed between 0 and $5 \mu \mathrm{g} / \mathrm{m}^{3}$ (77.47\% within the observation time range). Therefore, $5 \mu \mathrm{g} / \mathrm{m}^{3}$ was used as the standard for determining high or low $\mathrm{SO}_{2}$ concentration in this study. As shown in Figure 3 (which includes data for the duration of the experiment), the wind mostly originated from the southwest during the observation period. When these data were analyzed in relation to the equipment installation location and surrounding environment (Figure 1), it could be concluded that the results of this experiment were less affected by the sailing ships and that the main source of $\mathrm{SO}_{2}$ is the discharge of berthing ships and the pollution sources on the shore.

The arrival and departure of ships at the dock are considered to be a major factor affecting air quality. Therefore, we counted the distribution of $\mathrm{SO}_{2}$ during these two periods, respectively. The results displayed in Figure 4 show that $\mathrm{SO}_{2}$ concentration in the six observation groups is higher during the ships' arrival and departure times than at times when there was no movement of ships in or out of the dock. Therefore, all six sets of observations reflect the positive impact of fuel switching on air quality. Moreover, berths around Monitor-1 are only for ocean-going vessels, while berths around Monitor-2 are for river vessels and ocean-going vessels. To a certain extent, this may have led to a difference in the concentration of $\mathrm{SO}_{2}$ observed between the monitors. At Monitor-2, the concentrations of $\mathrm{SO}_{2}$ measured were higher, but the differences between periods of ship movement and periods of no ship movement were smaller compared to that of Monitor-1.

In Figure 5, we can see the difference in the overall distribution of the average $\mathrm{SO}_{2}$ concentrations per hour in two different contexts. Within one hour of a ship's arrival at or departure from the dock, the time quantum for $\mathrm{SO}_{2}$ concentrations exceeded $5 \mu \mathrm{g} / \mathrm{m}^{3}$, which was higher than that during no ship movement period. Meanwhile, the overall distribution of $\mathrm{SO}_{2}$ was also slightly larger when a ship arrived at or departed from the dock. In addition, there are more ship berths to the west of Monitor-2; therefore, results could be significantly underestimated at this point, considering the prevalent wind direction.

From Figures 4 and 5, we can see that ships' arrival and departure at the dock are a relatively obvious influence on air quality; however, there is no quantitative index. In addition, wind speed and direction can also produce monitoring results which are difficult to assess. Therefore, the DID model discussed in section 2.3 was used for analysis and calculation, and the results are shown in Table 2. We 
TABLE 1: DID model parameters.

\begin{tabular}{|c|c|c|c|}
\hline & $\begin{array}{l}\text { No ship movement in or out of the dock } \\
\qquad(d t=0)\end{array}$ & $\begin{array}{l}\text { Movement of ship(s) in or out of the dock } \\
\qquad(d t=1)\end{array}$ & Difference \\
\hline $\begin{array}{l}\text { Downwind (treatment group, } \\
d u=1 \text { ) }\end{array}$ & $\alpha_{0}+\alpha_{1}$ & $\alpha_{0}+\alpha_{1}+\alpha_{2}+\alpha_{3}$ & $\Delta Y=\alpha_{2}+\alpha_{3}$ \\
\hline $\begin{array}{l}\text { No downwind (control group, } \\
d u=0 \text { ) }\end{array}$ & $\alpha_{0}$ & $\alpha_{0}+\alpha_{2}$ & $\Delta Y=\alpha_{2}$ \\
\hline DID model estimation & $\alpha_{1}$ & $\alpha_{1}+\alpha_{3}$ & $\Delta Y=\alpha_{3}$ \\
\hline
\end{tabular}

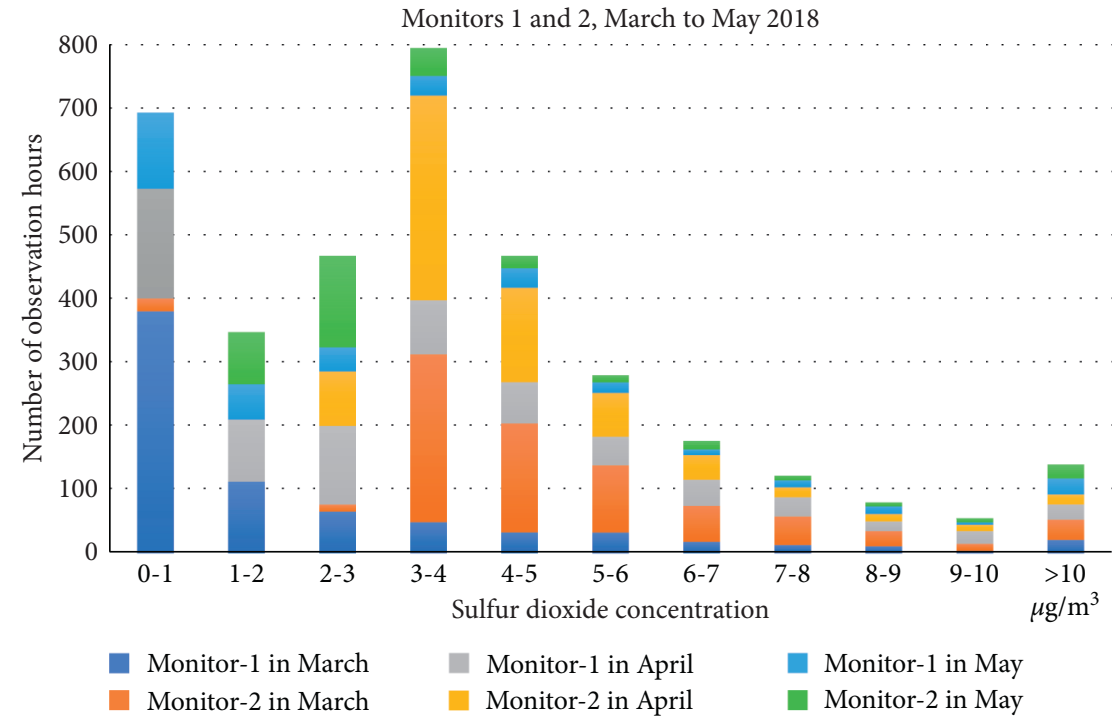

Figure 2: Overall distribution of the average $\mathrm{SO}_{2}$ concentrations per hour observed at the two monitoring points, where the interval is $1 \mu \mathrm{g} /$ $\mathrm{m}^{3}$, and the number of observation hours in each concentration interval were counted.

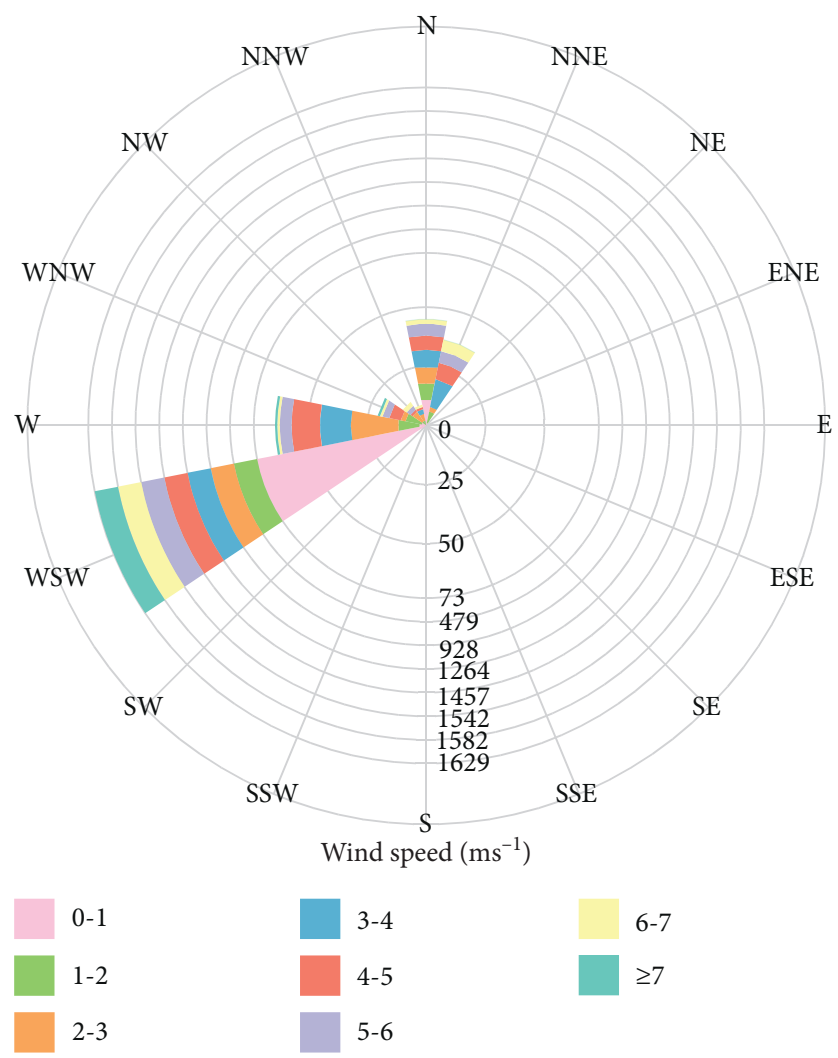

FIgURE 3: Wind speed and direction per hour. The numbers on the diagram are nonevenly spaced scale lines. 


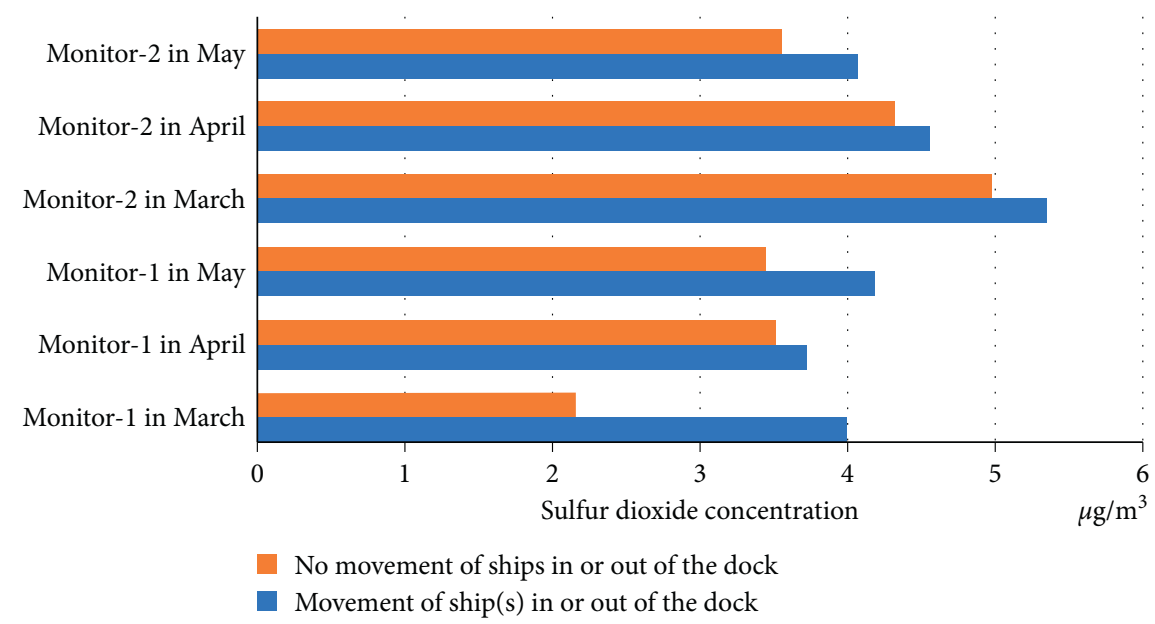

FIGURE 4: Average $\mathrm{SO}_{2}$ concentration within one hour of ships' arrival or departure versus periods of no ship movement in or out of the dock.

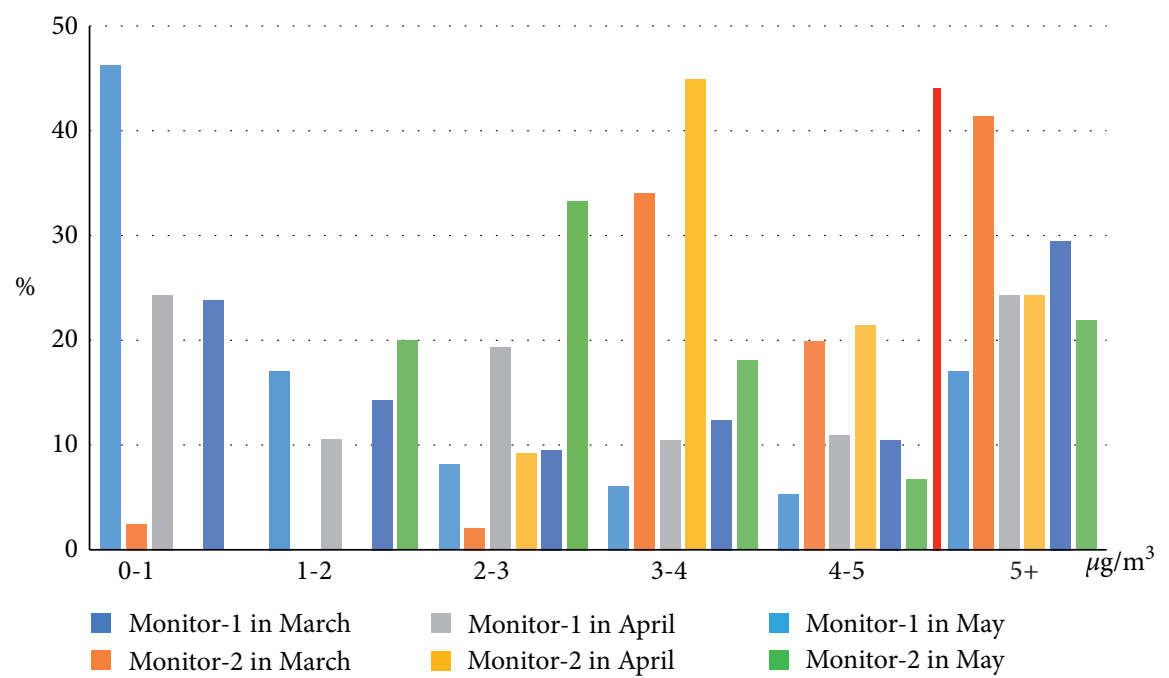

(a)

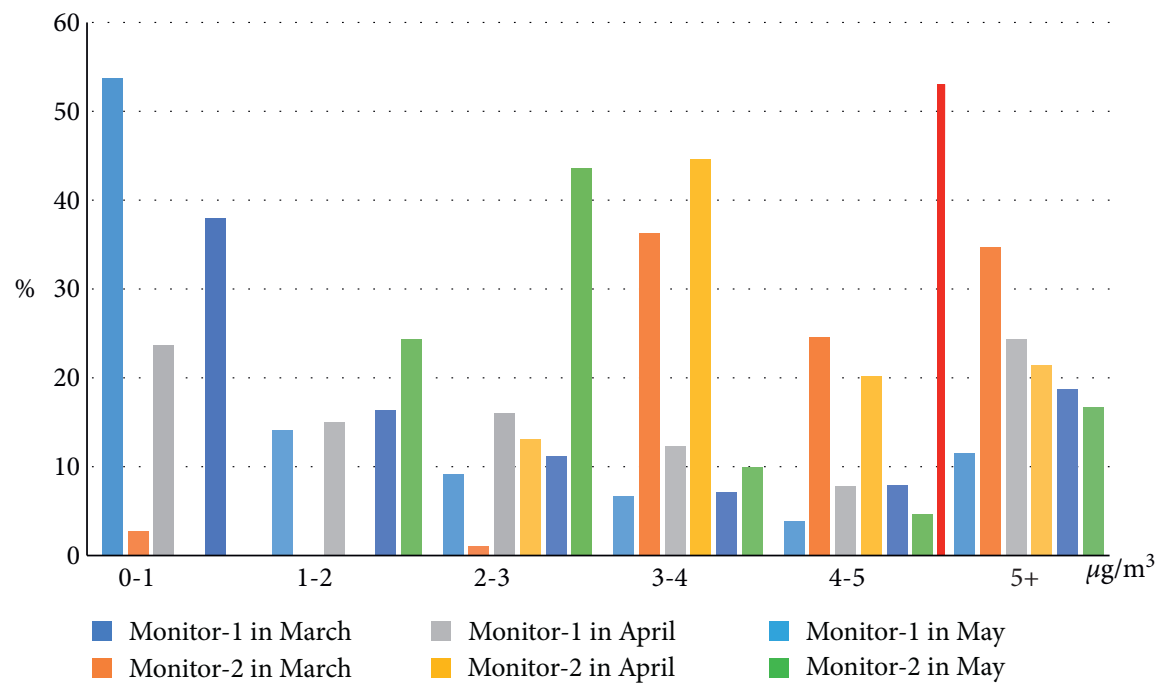

(b)

Figure 5: Percentage distribution of average $\mathrm{SO}_{2}$ concentrations per hour for (a) periods of ship movement in or out the dock versus (b) periods of no ship movement in or out the dock. 
TABLE 2: DID model results.

\begin{tabular}{|c|c|c|c|}
\hline & $\begin{array}{l}\text { No ship movement in or out of the dock } \\
\qquad(d t=0)\end{array}$ & $\begin{array}{l}\text { Movement of ship(s) in or out of the dock } \\
\qquad(d t=1)\end{array}$ & Difference \\
\hline \multicolumn{4}{|c|}{ Monitoring point 1, March 2018} \\
\hline $\begin{array}{l}\text { Downwind (treatment group, } \\
d u=1 \text { ) }\end{array}$ & 2.25 & 4.24 & 1.99 \\
\hline No wind (control group, $d u=0$ ) & 3.18 & 1.42 & -1.76 \\
\hline DID model estimation & -0.93 & 2.82 & 3.75 \\
\hline \multicolumn{4}{|c|}{ Monitoring point 2, March 2018} \\
\hline $\begin{array}{l}\text { Downwind (treatment group, } \\
d u=1 \text { ) }\end{array}$ & 5.06 & 5.35 & 0.29 \\
\hline No wind (control group, $d u=0$ ) & 4.02 & 5.22 & 1.2 \\
\hline DID model estimation & 1.04 & 0.13 & -0.91 \\
\hline \multicolumn{4}{|c|}{ Monitoring point 1, April 2018} \\
\hline $\begin{array}{l}\text { Downwind (treatment group, } \\
d u=1 \text { ) }\end{array}$ & 3.56 & 3.86 & 0.3 \\
\hline No wind (control group, $d u=0$ ) & 2.72 & 2.18 & -0.54 \\
\hline DID model estimation & 0.84 & 1.68 & 0.84 \\
\hline \multicolumn{4}{|c|}{ Monitoring point 2, April 2018} \\
\hline $\begin{array}{l}\text { Downwind (treatment group, } \\
d u=1 \text { ) }\end{array}$ & 4.33 & 4.61 & 0.28 \\
\hline No wind (control group, $d u=0$ ) & 4.11 & 3.95 & -0.16 \\
\hline DID model estimation & 0.22 & 0.66 & 0.44 \\
\hline \multicolumn{4}{|c|}{ Monitoring point 1, May 2018} \\
\hline $\begin{array}{l}\text { Downwind (treatment group, } \\
d u=1 \text { ) }\end{array}$ & 3.25 & 3.71 & 0.46 \\
\hline No wind (control group, $d u=0$ ) & 6.02 & 9.91 & 3.89 \\
\hline DID model estimation & -2.77 & -6.2 & -3.43 \\
\hline \multicolumn{4}{|c|}{ Monitoring point 2, May 2018} \\
\hline $\begin{array}{l}\text { Downwind (treatment group, } \\
d u=1 \text { ) }\end{array}$ & 3.52 & 4.15 & 0.63 \\
\hline No wind (control group, $d u=0$ ) & 3.96 & 2.96 & -1 \\
\hline DID model estimation & -0.44 & 1.19 & 1.63 \\
\hline
\end{tabular}

calculated the average $\mathrm{SO}_{2}$ concentration per period. All measurement data were divided into the treatment group and control group, and the ships' arrival and departure times were taken as the control conditions. Based on the calculation results of the DID model, the influence of the two factors (i.e., ships' arrival or departure time and wind speed and direction) on the concentration of $\mathrm{SO}_{2}$ was judged.

In the treatment group, the effect of arrival or departure time is obvious and significant, whereas it is not obvious in the control group. This means that $\mathrm{SO}_{2}$ concentration rose significantly in the period of ship arrival or departure when the wind direction was southwest. In contrast, when the wind direction is not southwest, the variation trend of $\mathrm{SO}_{2}$ concentration is not obvious in the period of ship arrival or departure. Similarly, when there is no arrival and departure of ships, the influence of wind direction on the changing trend of $\mathrm{SO}_{2}$ is not obvious. In contrast, when ships are moving in or out of the dock, the concentration of $\mathrm{SO}_{2}$ increases significantly when the wind is downwind. Finally, two sets of DID model results $(\Delta \Delta Y)$ are negative, which can be attributed to the small number of data samples. In spite of this, four sets of DID model results $(\Delta \Delta Y)$ are positive and present the impact of these two factors on $\mathrm{SO}_{2}$ concentrations. On the whole, the calculation results of the DID model mentioned above show that the $\mathrm{SO}_{2}$ concentration in the air of the port area increases due to the use of high-sulfur fuel, and its influence is especially significant when the wind direction is southwest.

In addition, we conducted statistics on the time period during which the sulfur dioxide concentration measured at the two monitoring points exceeded $5 \mu \mathrm{g} / \mathrm{m}^{3}$. As shown in Figure 6 , when the $\mathrm{SO}_{2}$ concentration exceeded $5 \mu \mathrm{g} / \mathrm{m}^{3}$ at only one monitoring point when measured at two points, both frequency ratios of the arrival and departure of ships were higher than that within the period in which the $\mathrm{SO}_{2}$ concentration was less than $5 \mu \mathrm{g} / \mathrm{m}^{3}$ at both monitoring points. In other words, there is a positive correlation between the high concentration of $\mathrm{SO}_{2}$ and the increased frequency of ships arriving and departing from the port area. This result also reflects the positive impact of fuel switching.

Several studies have monitored and assessed the impact of ECAs [21-24, 27-29]. However, the impact of individual ship activities on air quality is rarely monitored, making it virtually impossible to assess the impact of ECA policies on air quality in local areas such as wharves. The activities of ships and personnel in dock areas tend to be relatively frequent, and ship emissions directly affect public health. Therefore, this study sought to establish monitoring data on ship emissions in one of Shanghai's main ports by installing two monitoring stations at Waigaoqiao wharf to explore the relationships between $\mathrm{SO}_{2}$ concentrations, wind speed and wind direction, and ships' arrival and departure times. 


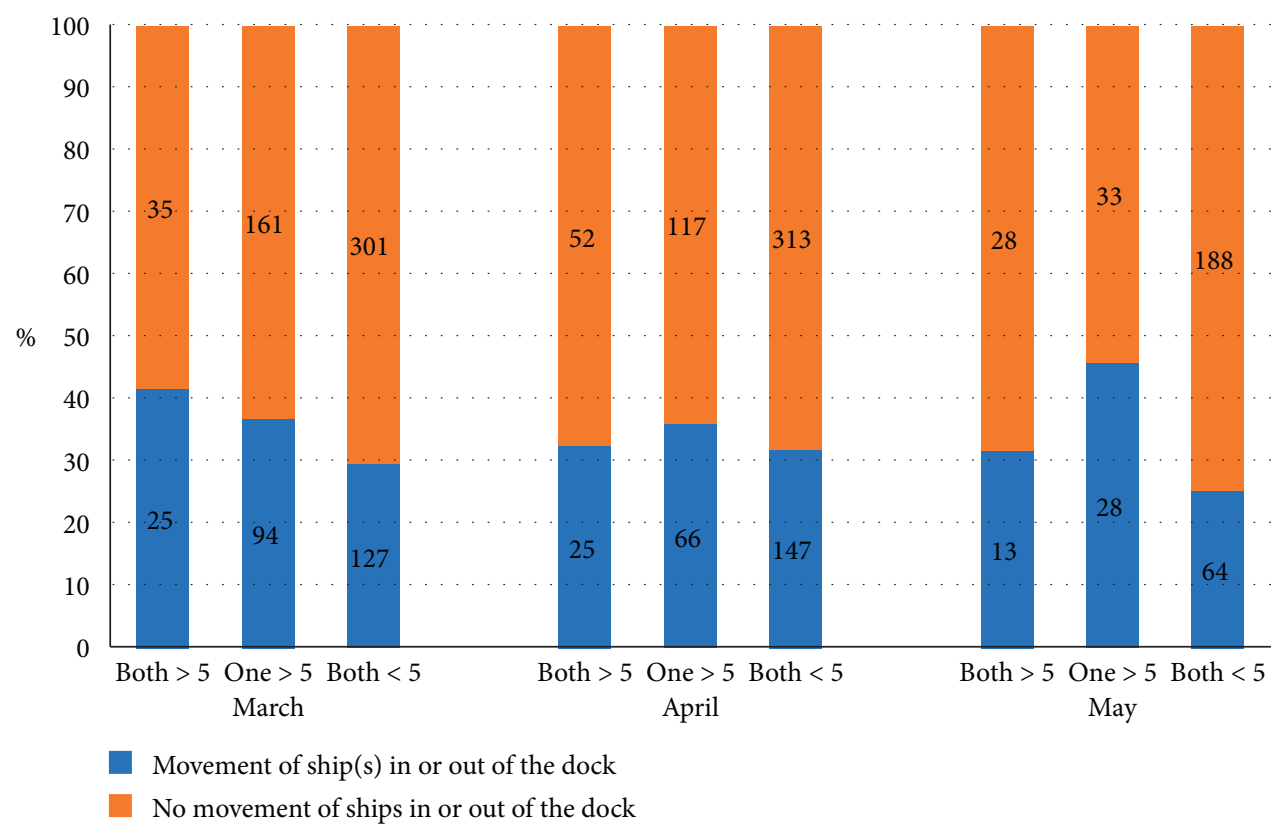

FIGURE 6: $\mathrm{SO}_{2}$ concentrations during periods of ship movement in or out of the dock versus periods of no movement of ship(s) in or out of the dock expressed in percentage terms. For each month (March, April, or May), $\mathrm{SO}_{2}$ concentrations were divided into three categories: $\mathrm{SO}_{2}$ concentrations at both monitoring points greater than $5 \mu \mathrm{g} / \mathrm{m}^{3}$ (both $>5$ ), $\mathrm{SO}_{2}$ concentrations greater than $5 \mu \mathrm{g} / \mathrm{m}^{3}$ at only one monitoring station (one $>5$ ), $\mathrm{SO}_{2}$ concentrations less than $5 \mu \mathrm{g} / \mathrm{m}^{3}$ at both stations (both $<5$ ).

Considering the results presented in Figures 4-6, it can be concluded that ship emissions during the arrival or departure of ships significantly affect the airborne $\mathrm{SO}_{2}$ concentration in the study area. The results of the DID model presented in Table 1 further indicate that $\mathrm{SO}_{2}$ concentration in the air increases significantly due to the use of high-sulfur fuel when the wind direction is southwest. This is significant in the context of recently implemented policies which stipulate that the FSC cannot exceed $0.5 \%(\mathrm{~m} / \mathrm{m})$ during berthing within ECAs, excluding the first hour postarrival and the last hour predeparture. Thus, we were able to clarify the impact of ECA policy on air quality in port areas. We found that the recently implemented policies may need amendment in the future to consider our findings.

\section{Conclusions}

The implementation of the ECA policy can effectively reduce the harm caused by ship emissions. How to evaluate the impact of the implementation of this policy on the environment is a research topic of interest. In this study, two $\mathrm{SO}_{2}$ monitoring stations were installed on the bridge crane in Waigaoqiao Dock, Shanghai, China, which allowed data to be obtained from March 2018 to May 2018. To analyze the factors that caused a change in the $\mathrm{SO}_{2}$ concentration, we collected the data on the wind speed and direction as well as the arrival and departure times of ships at the port in the same period and normalized them to one hour. Then, the DID model was used to evaluate the impact of policy implementation.

The overall airborne distribution of $\mathrm{SO}_{2}$ at Waigaoqiao Dock was obtained. It was determined that the concentration of $\mathrm{SO}_{2}$ was low (less than $5 \mu \mathrm{g} / \mathrm{m}^{3}$ ) $77.47 \%$ of the time. The distribution of wind speed and direction indicated that there was little change in the wind direction during the study period. The data observed at the monitoring stations were mostly attributable to the pollution sources in the berth and on the shore. The change in $\mathrm{SO}_{2}$ concentration during periods of ship movement in or out of the dock compared to when there was no ship activity at the dock is indicative of the contribution of a ship's emissions to the $\mathrm{SO}_{2}$ concentration in the air. The result of the DID model shows that the concentration of $\mathrm{SO}_{2}$ in the air of the port area increased due to the use of high-sulfur fuel and that its influence is especially significant when the wind direction is downwind. This finding is relevant to the implementation of ECA policy, which requires that the FSC cannot exceed $0.5 \%(\mathrm{~m} / \mathrm{m})$ during berthing within the ECAs, except for the first hour after arrival and the last hour before departure. The results of this study can be used as the basis for understanding ship emissions and atmospheric processes within dock areas under ECA policy. Subsequently, more attention should be paid to the effects of sailing ship emissions.

\section{Data Availability}

The data used to support the findings in this study are available at https:/data.mendeley.com/datasets/427wfrck7w/ draft?a=883bb7b4-b9f1-4549-b10c-9ad9939a3e61.

\section{Conflicts of Interest}

The authors declare no conflicts of interest. 


\section{Acknowledgments}

The authors would like to thank Pudong Maritime Safety Administration of the People's Republic of China for their support in coordinating the field measurements. This research was supported by the National Natural Science Foundation of China (Grant nos. 41701523 and 61703271), the National Key Research and Development Project of China (Grant no. 2020YFC1511901), and the Special Development Fund for China (Shanghai) Pilot Free-Trade Zone.

\section{References}

[1] UNCTAD, "World seaborne trade by types of cargo and by group of economies, annual, United Nations Conference on Trade and Development," 2017, https://unctadstat.unctad. org/wds/TableViewer/tableView.aspx?ReportId=32363.

[2] V. Eyring, I. S. A. Isaksen, T. Berntsen et al., "Transport impacts on atmosphere and climate: shipping," Atmospheric Environment, vol. 44, no. 37, pp. 4735-4771, 2010.

[3] A. Sorooshian and H. T. Duong, "Ocean emission effects on aerosol-cloud interactions: insights from two case studies," Advances in Meteorology, vol. 2010, Article ID 301395, 9 pages, 2010.

[4] C. Gencarelli, I. Hedgecock, F. Sprovieri, G. Schürmann, and N. Pirrone, "Importance of ship emissions to local summertime ozone production in the mediterranean marine boundary layer: a modeling study," Atmosphere, vol. 5, no. 4, pp. 937-958, 2014.

[5] H. Liu, M. Fu, X. X Jin et al., "Health and climate impacts of ocean-going vessels in East Asia," Nature Climate Change, vol. 6, no. 11, pp. 1037-1041, 2016.

[6] G.-H. Yu, S. Park, S.-K. Shin, K.-H. Lee, and H.-G. Nam, "Enhanced light absorption due to aerosol particles in ship plumes observed at a seashore site," Atmospheric Pollution Research, vol. 9, no. 6, pp. 1177-1183, 2018.

[7] J. X. Zhou, S. Zhou, and Y. Q. Zhu, "Characterization of particle and gaseous emissions from marine diesel engines with different fuels and impact of after-treatment technology," Energies, vol. 10, no. 8, p. 14, Article ID 1110, 2017.

[8] IMO, "Sulphur oxides (SOx)-regulation 14," 2017, http:// www.imo.org/en/OurWork/Environment/PollutionPrevention/ AirPollution/Pages/Sulphur-oxides-(SOx)-Regulation-14.aspx.

[9] IMO, "Emission control areas (ECAs) designated under MARPOL Annex VI," 2017, http://www.imo.org/en/OurWork/ Environment/PollutionPrevention/AirPollution/Pages/EmissionControl-Areas-(ECAs)-designated-under-regulation-13-of-MAR POL-Annex-VI-(NOx-emission-control.

[10] Standing Committee of the National People's Congress, "Atmospheric pollution prevention and control law of the People's Republic of China," 2015, http://english.court.gov. cn/2016-04/15/content_24565639.htm.

[11] Ministry of Transport of the People's Republic of China, "Marine emission control area plan for Pearl river delta, Yangtzy river delta, Bohai Rim area," 2015, http://www.gov. cn/xinwen/2015-12/04/content_5019932.htm.

[12] Shanghai Municipal Bureau of Statistics, "The statistic communique of Shanghai on the 2017 national economy and social development," 2017, http://www.stats.gov.cn/english/ pressrelease/201802/t20180228_1585666.html.

[13] Y. Y. Huang, Q. W. Yan, and C. R. Zhang, "Spatial-temporal distribution characteristics of PM2.5 in China in 2016,"
Journal of Geovisualization and Spatial Analysis, vol. 2, no. 12, pp. 1-18, 2018.

[14] X. N Wang, Y. Shen, Y. F Lin et al., "Atmospheric pollution from ships and its impact on local air quality at a port site in Shanghai," Atmospheric Chemistry and Physics, vol. 19, no. 9, pp. 6315-6330, 2019.

[15] Y. Y Zhou, Y. Zhang, D. Ma et al., "Port-related emissions, environmental impacts and their implication on green traffic policy in Shanghai," Sustainability, vol. 12, no. 10, p. 17, 2020.

[16] J. J. Corbett, P. S. Fischbeck, and S. N. Pandis, "Global nitrogen and sulfur inventories for oceangoing ships," Journal of Geophysical Research: Atmospheres, vol. 104, no. D3, pp. 3457-3470, 1999.

[17] Y. González, S. Rodríguez, J. C. Trujillo, and R. García, "Ultrafine particles pollution in urban coastal air due to ship emissions," Atmospheric Environment, vol. 45, no. 28, pp. 4907-4914, 2011.

[18] M. Filonchyk and M. Peterson, "Air quality changes in Shanghai, China, and the surrounding urban agglomeration during the COVID-19 lockdown," Journal of Geovisualization and Spatial Analysis, vol. 4, no. 22, pp. 1-7, 2020.

[19] X. Geng, Y. Wen, C. Zhou, and C. Xiao, "Establishment of the sustainable ecosystem for the regional shipping industry based on system dynamics," Sustainability, vol. 9, no. 5, p. 18, Article ID 742, 2017.

[20] N. Mölders, S. Gende, and M. Pirhalla, "Assessment of cruiseship activity influences on emissions, air quality, and visibility in Glacier Bay National Park," Atmospheric Pollution Research, vol. 4, no. 4, pp. 435-445, 2013.

[21] L. Kattner, B. Mathieu-Üffing, J. P. Burrows et al., "Monitoring compliance with sulfur content regulations of shipping fuel by in situ measurements of ship emissions," Atmospheric Chemistry and Physics, vol. 15, no. 17, pp. 10087-10092, 2015.

[22] M. Yang, T. G. Bell, F. E. Hopkins, and T. J. Smyth, "Attribution of atmospheric sulfur dioxide over the English Channel to dimethyl sulfide and changing ship emissions," Atmospheric Chemistry and Physics, vol. 16, no. 8, pp. 47714783, 2016.

[23] L. Barregard, P. Molnar, J. E. Jonson et al., "Impact on population health of baltic shipping emissions," International Journal of Environmental Research and Public Health, vol. 16, no. 11, 11 pages, Article ID 1954, 2019.

[24] B. Alföldy, J. B. Lööv, F. Lagler et al., "Measurements of air pollution emission factors for marine transportation in SECA," Atmospheric Measurement Techniques, vol. 6, no. 7, pp. 1777-1791, 2013.

[25] J. Beecken, J. Mellqvist, K. Salo et al., "Emission factors of $\mathrm{SO}_{2} \mathrm{NO}_{\mathrm{x}}$ and particles from ships in Neva Bay from groundbased and helicopter-borne measurements and AIS-based modeling," Atmospheric Measurement Techniques, vol. 15, no. 9, pp. 5229-5241, 2015.

[26] F. Murena, L. Mocerino, F. Quaranta et al., "Impact on air quality of cruise ship emissions in Naples, Italy," Atmospheric Environment, vol. 187, pp. 70-83, 2018.

[27] Q. Zhang, Z. Q Zheng, Z. Wan et al., "Does emission control area policy reduce sulfur dioxides concentration in Shanghai?" Transportation Research Part D, vol. 81, Article ID 102289, 2020.

[28] Z. Wan, X. J Zhou, Q. Zhang et al., "Do ship emission control areas in China reduce sulfur dioxide concentrations in local air? A study on causal effect using the difference-in-difference model," Marine Pollution Bulletin, vol. 149, Article ID 110506, 2019. 
[29] Y. N Zhang, F. Y Deng, H. L Man et al., "Compliance and port air quality features with respect to ship fuel switching regulation: a field observation campaign, SEISO-Bohai," Atmospheric Measurement Techniques, vol. 19, no. 7, pp. 4899-4916, 2019.

[30] M. S. Delgado and R. J. G. M. Florax, "Difference-in-differences techniques for spatial data: local autocorrelation and spatial interaction," Economics Letters, vol. 137, pp. 123-126, 2015.

[31] D. S. Chen, X. T. Wang, P. Nelson et al., "Ship emission inventory and its impact on the PM 2.5 air pollution in Qingdao Port, North China," Atmospheric Environment, vol. 166, pp. 351-361, 2017.

[32] A. W. E. Hodgson, P. Jacquinot, and P. C. Hauser, "Electrochemical sensor for the detection of $\mathrm{SO}_{2}$ in the low-ppb range," Analytical Chemistry, vol. 71, no. 14, pp. 2831-2837, 1999.

[33] H. Schlager, R. Baumann, M. Lichtenstern et al., "Aircraftbased trace gas measurements in a primary European ship corridor," Proceedings of the TAC-Conference, pp. 83-88, 2006.

[34] H. Agrawal, W. A. Welch, J. W. Miller et al., "Emission measurements from a crude oil tanker at sea," Environmental Science and Technology, vol. 42, no. 19, pp. 7098-7103, 2008.

[35] J. Moldanova, E. Fridell, O. Popovicheva et al., "Characterisation of particulate matter and gaseous emissions from a large ship diesel engine," Atmospheric Environment, vol. 43, no. 16, pp. 2632-2641, 2009.

[36] J. M. Balzani Loov, B. Alfoldy, L. F. L. Gast et al., "Field test of available methods to measure remotely SOx and NOx emissions from ships," Atmospheric Measurement Techniques, vol. 7, no. 8, pp. 2597-2613, 2014. 